\title{
PELATIHAN PEMASARAN ONLINE BAGI KELOMPOK USAHA HERBAL
}

Nurhidayah Layoo ${ }^{1}$, Yusuf Ayuba², Ramadhani Chaniago ${ }^{3}$

${ }^{1}$ Afiliasi/Institusi (Fakultas Ekonomi dan Bisnis Univeristas Muhammadiyah Luwuk Banggai)

${ }^{2}$ Afiliasi/Institusi (Fakultas Teknik Univeristas Muhammadiyah Luwuk Banggai)

${ }^{3}$ Afiliasi/Institusi (Fakultas Pertanian Univeristas Muhammadiyah Luwuk Banggai)

E-mail: nhlayoo@gmail.com

Article History:

Received: 20-08-2021

Revised: 15-09-2021

Accepted: 27-09-2021

Keywords: Kelompok Herbal, pemasaran, media sosial

\begin{abstract}
Permasalahan yang dihadapi kelompok usaha herbal di Batui Selatan pada masa pandemi covid 19 adalah penurunan penjualan hampir semua jenis produk, tidak memiliki dan menguasai teknologi digital yang dapat menjangkau konsumen yang lebih banyak dan melayaninya dengan minim kontak fisik, kurangnya pengetahuan mitra dalam menentukan masa simpan produk, merek yang belum terdaftar di direktorat hak atas kekayaan intelektual, tidak ada kontrak kerjasama antar kelompok sehingga tidak dapat saling menguatkan dikala kondisi lingkungan eksternal dan internal usaha kurang kondusif. Solusi yang ditawarkan kepada mitra adalah pelatihan strategi pemasaran yang meliputi strategi produk, harga, promosi dan distribusi; mengembangkan aplikasi pemasaran online; memberikan pelatihan dan pendampingan cara pemasaran melalui media sosial; mengembangkan kemitraan antar kelompok dalam aspek produksi dan pemasaran secara berkelanjutan. Luaran yang dihasilkan berupa satu artikel yang dipublikasikan melalui Jurnal terakreditasi Sinta, meningkatnya pengetahuan strategi pemasaran yang meliputi strategi harga, promosi dan distribusi, meningkatnya keterampilan pemasaran melalui media sosial IG, FB, dan WA, serta video kegiatan yang diunggah di kanal Youtube https://youtu.be/2uWxOfHOugY
\end{abstract}

\section{Pendahuluan}

Batui Selatan adalah satu satunya kecamatan diantara 23 kecamatan yang ada di Kabupaten Banggai yang memiliki banyak kelompok UKM yang khusus memproduksi produk-produk herbal, tercatat 10 kelompok yang tersebar di lima desa. Setiap kelompok terdiri dari enam hingga 11 orang anggota yang semuanya adalah ibu-ibu. Mereka tidak hanya memproduksi aneka olahan herbal seperti sari jahe, sari kunyit, sari temulawak, sari mengkudu, Virgin Coconut Oil (VCO), kapsul herbal, stick daun kelor, stick daun sirsak, kaktus pegagan, stik wortel, hand sanitizer daun sirih, namun juga membudidayakan sebagian dari tanaman berkhasiat obat tersebut sebagai sumber bahan baku.

Sejak awal hingga sekarang kelompok usaha herbal di Batui Selatan dibentuk dan dikembangkan oleh JOB Pertamina Medco E\&P Tomori Sulawesi sebagai bagian dari implementasi corporate social responsibility perusahaan yang disebut dengan program kampung herbal. 
Kampung herbal terus berkembang mulai dari jumlah kelompok, varian produk yang dihasilkan, kualitas, aneka kemasan, hingga legalitas usaha. Kementerian Riset Teknologi dan Pendidikan Tinggi pada tahun 2016 pun turut berkontribusi dalam pengembangan dua diantara kelompok usaha herbal ini melalui program Iptek bagi Masyarakat. Outputnya adalah hasil uji laboratorium untuk produk sari jahe, sari kunyit, sari temulawak, sari mengkudu dan VCO dari laboratorium terakreditasi, selain itu peningkatan manajemen kelompok dan manajemen persediaan bahan baku.

Sebanyak empat kelompok diantara 10 kelompok herbal yang ada di Batui Selatan akan dijadikan mitra dalam program PKM ini, karena pada kelompok ini ditemukan beberapa permasalahan. Sebelum pandemi Covid 19 kelompok mitra sangat aktif berproduksi, setiap pekan rata-rata memproduksi sekitar 400-1000 unit per item produk herbal. Wilayah pemasaran hingga keluar dari Kabupaten Banggai. Tidak pernah ada barang yang diretur oleh distributor karena alasan tidak terjual, distributor yang telah bekerjasama antara lain gerai ole ole di ruang tunggu bandara Syukuran Aminudin Amir Luwuk, Swalayan Golden Hill yang merupakan toko ritel modern paling besar di Kabupaten Banggai, dan minimal satu kios di setiap kecamatan yang ada di daerah ini. Selain itu harga bahan baku relatif stabil serta konsolidasi anggota kelompok sangat rutin. Berikut foto-foto sebagian produk yang dihasilkan kelompok UKM Herbal di Kecamatan Batui Selatan.
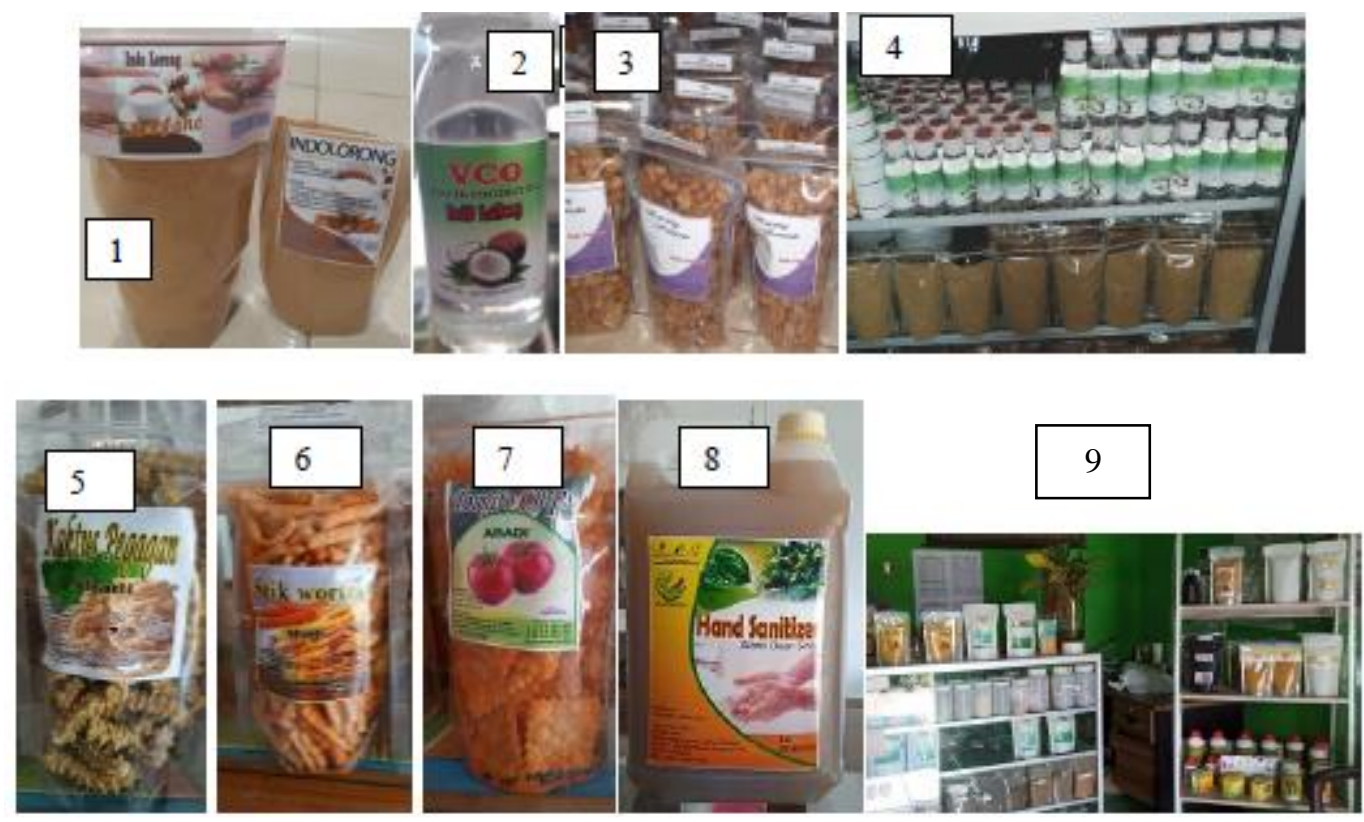

Gambar 1. Foto sebagian produk UKM Herbal di Batui Selatan

Keterangan Gambar :

Produk UKM Indolorong : 1. Sari Jahe; 2. VCO; 3. Kacang Kentaki

Produk UKM Cahaya Anugerah : 4. VCO, Sari Jahe, Sari Kunyit, Sari Temulawak 
Produk UKM Sipa MaseMase : 5. kaktus pegagan, 6.stik wortel, 7. tomato chips 8. Hand Sanitizer daun sirih, 9. Kapsul Herbal, VCO, Sari Mengkudu, Sari Jahe, Sari Kunyit, Sari komplit

Sejak April hingga Oktober 2020, penjualan produk sari jahe meningkat tajam karena khasiatnya yang diyakini masyarakat dapat menangkal covid 19, namun pada saat bersamaan harga bahan baku jahe segar meningkat hingga 100\% dari sebelumnya Rp 20.000/Kg meningkat menjadi $\mathrm{Rp}$ 40.000/Kg bahkan mencapai Rp 75.000/Kg. Namun kenaikan penjualan sari jahe tidak memberikan keuntungan yang signifikan karena harga bahan baku naik tapi harga jual produk tetap. Penjualan hampir semua jenis produk yang dihasilkan mengalami penurunan drastis, banyak produk pada distributor yang dikembalikan bahkan distributor di Bandara Syukuran Aminudin Amir menghentikan kerjasama distribusi. Sehingga frekuensi produksi yang sebelumnya 3-5 kali sebulan menjadi hanya sekali sebulan bahkan tidak ada produksi, tidak pernah lagi ada pengiriman produk ke distributor maupun ke konsumen di luar daerah. Hasil penelitian (Layoo et al., 2020) bahwa program kampung herbal masih kurang memuaskan penerima manfaat karena tidak adanya pendamping teknis lokal dan kurangnya mitra penjualan. Kunjungan konsumen ke rumah produksi mitra menjadi sangat terbatas, distribusi produk dan mobilitas anggota kelompok untuk memasarkan hasil produksi secara langsung pun mengalami kendala karena himbauan pemerintah "di Rumah saja". Sementara mitra masih mengandalkan pemasaran konvensional melalui kontak fisik dengan konsumen dan distributor. (Diko et al., 2020) menemukan bahwa pemasaran produk herbal di Batui Selatan masih mengandalkan cara offline, belum menggunakan platform digital atau aplikasi pemasaran secara online Setiap kelompok mitra memiliki merek produk masing-masing, namun hingga saat ini belum ada satupun dari merek tersebut yang terdaftar di Direktorat Jenderal Kekayaan Intelektual sehingga rawan untuk dipalsukan, padahal merek dapat menjadi sebuah aset usaha. Meskipun merk produk berbeda-beda, akan tetapi jenis produk yang dihasilkan relatif seragam, sehingga terjadi persaingan yang kurang sehat. Mestinya ada kemitraan strategis antar kelompok yang saling menguntungkan dan berkelanjutan sehingga dapat saling menguatkan dikala kondisi lingkungan eksternal dan internal usaha kurang kondusif serta mewujudkan terbentuknya sentra produksi herbal di Kabupaten Banggai.

Berdasarkan kesepakatan bersama mitra bahwa permasalahan prioritas untuk diselesaikan selama pelaksanaan kegiatan adalah: a. Masalah penurunan penjualan, terutama pada masa pandemi covid penjualan hampir semua jenis produk menurun drastis b. Masalah penguasaan teknologi digital, dimana mitra tidak memiliki dan menguasai teknologi yang dapat menjangkau konsumen yang lebih banyak dan melayaninya tanpa kontak fisik c. Masalah penentuan kadaluarsa produk, yaitu kurangnya pengetahuan mitra dalam menentukan masa simpan produk herbal d. Masalah 
keabsahan merek, yakni merek belum terdaftar di direktorat hak atas kekayaan intelektual, sehingga rawan untuk dipalsukan e. Masalah kemitraan yakni tidak ada kontrak kerjasama antar kelompok sehingga tidak dapat saling mendukung disaat kondisi lingkungan eksternal dan internal kurang kondusif.

Tujuan pelaksanaan kegiatan ini adalah Meningkatnya pengetahuan dan keterampilan mitra tentang strategi pemasaran yang meliputi strategi harga, promosi dan distribusi, meningkatnya keterampilan menggunakan media sosial IG, FB dan WA untuk pemasaran online yang dapat dioperasikan oleh minimal 2 orang anggota dalam setiap kelompok.

\section{Metode}

Metode yang digunakan terkait solusi yang ditawarkan untuk mengatasi permasalahan mitra sebagaimana gambar berikut.

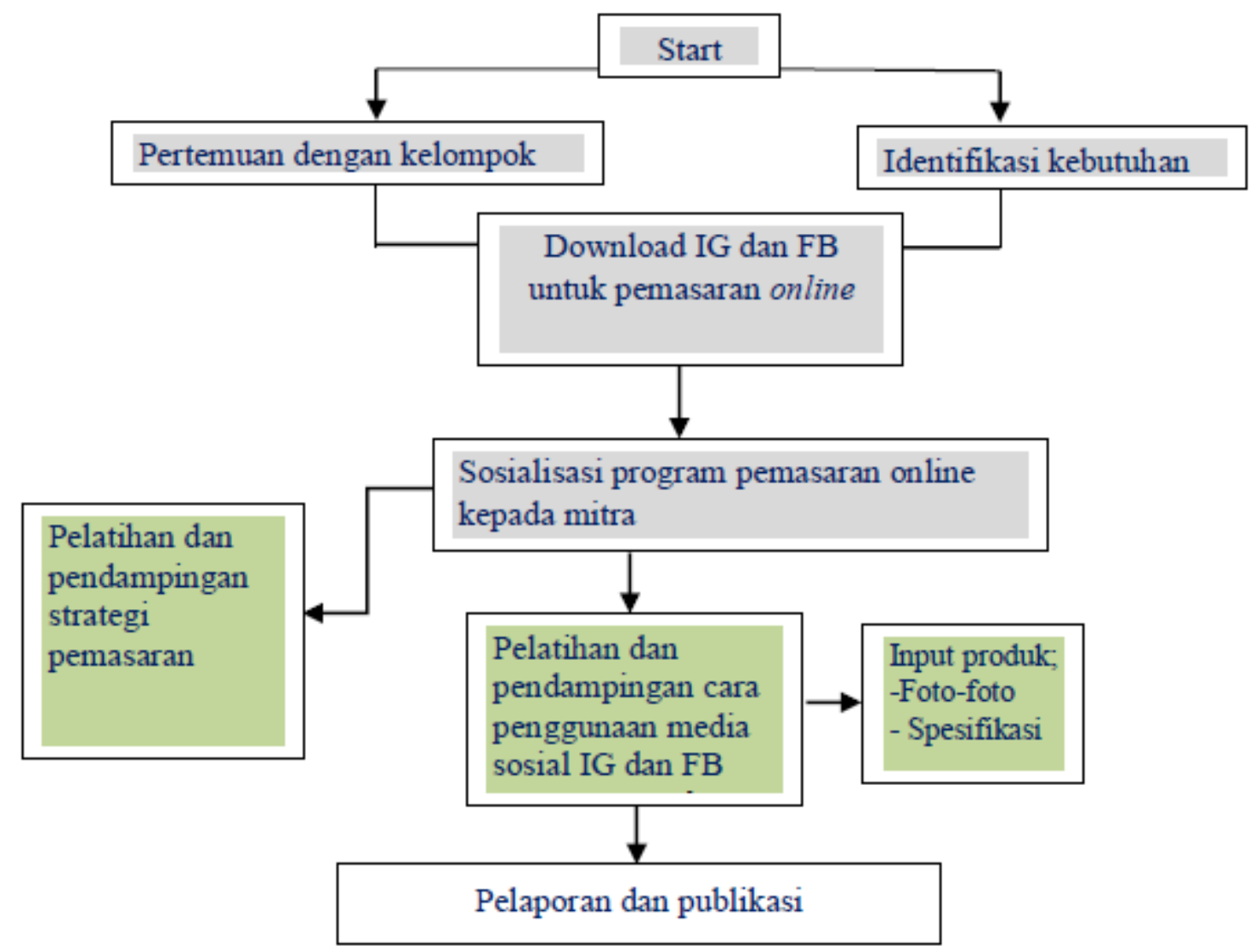

Gambar 2. Skema Metode Pelaksanaan

Pihak-pihak yang terlibat dalam kegiatan pengabdian masyarakat ini adalah Lembaga Penelitian, Pengembangan dan Pengabdian Masyarakat Universitas Muhammadiyah Luwuk, yang 
bertindak sebagai donatur program, Tim kerja Universitas Muhammadiyah Luwuk sebagai pelaksana program atau fasilitator kegiatan di lapangan sekaligus sebagai mediator antara pemerintah dan masyarakat pelaku usaha kecil, anggota kelompok usaha herbal yang menjadi mitra kerjasama sebagai penerima program dan pemerintah setempat yakni pemerintah desa dan pemerintah kecamatan melalui kebijakan-kebijakan yang mendukung program ini sehingga dapat berkelanjutan.

Deskripsi produk teknologi yang akan diimplementasikan ke UKM, diuraikan berikut:

1. Penyiapan perangkat berbasis android melalui media sosial IG dan FB. Kegiatan ini dilakukan oleh tim pelaksana di kampus.

2. Sosialisasi program dan downlaod aplikasi IG dan FB ke perangkat telekomunikasi anggota kelompok UKM Herbal. Sosialisasi program adalah pengenalan seluruh rangkaian kegiatan yang akan diimplementasikan kepada kelompok mitra

3. Pelatihan dan pendampingan strategi pemasaran. Strategi pemasaran meliputi materi tentang strategi penetapan harga terhadap produk-produk yang dihasilkan mitra ketika terjadi perubahan harga bahan baku dan perubahan tingkat permintaan, strategi promosi yang sesuai pada media online dan strategi distribusi pada penjualan produk secara online. kemudian merek mitra akan didaftarkan pada Direktorat Kekayaan Intelektual.

4. Pelatihan dan pendampingan cara penggunaan aplikasi : - Penginputan produk meliputi input foto-foto produk dan spesifikasi masing-masing produk yang dihasilkan kelompok UKM mitra - Pengelolaan transaksi (merchant/toko) meliputi konfirmasi pembayaran dan pengiriman barang.

5. Membangun kemitraan antar kelompok melalui kerjasama yang meliputi aspek produksi dan penggunaan aplikasi pemasaran online secara berkelanjutan. Kerjasama ini akan dituangkan dalam bentuk nota kesepahaman (MoU) antar kelompok.

Keempat kelompok mitra terlibat sepenuhnya dalam pelaksanaan program ini mulai dari merumuskan masalah yang dihadapi dan menyepakati program yang dapat dilaksanakan, menyediakan tempat pertemuan, menyiapkan perangkat yang diperlukan untuk instalasi aplikasi pemasaran online, menyediakan bahan-bahan yang akan diinput kedalam aplikasi, serta mengikuti seluruh rangkaian pelatihan. Evaluasi pelaksanaan program akan dilaksanakan melalui mekanisme pretest dan post test terhadap 1) pengetahuan anggota kelompok mitra tentang materi yang diberikan dalam progran ini, 2) keterampilan penggunaan IG dan FB untuk pemasaran online, dan 3) sikap anggota kelompok mitra tentang program yang diimplementasikan kepada mereka. 


\section{Hasil}

Kegiatan PKM kelompok minuman herbal di Batui Selatan dilaksanakan selama 3 bulan. merupakan upaya bersama memecahkan permasalahan prioritas mitra yang telah disepakati sebelumnya, melalui metode pelatihan dan pendampingan. Kegiatan tersebut diuraikan secara simultan berikut ini.

1. Pelatihan strategi pemasaran yang meliputi strategi produk, harga, promosi dan distribusi Kegiatan ini dilaksanakan dalam bentuk pelatihan strategi produk, harga, promosi dan distribusi sebanyak satu kali, bertempat di rumah ketua kelompok Sipa Mase Mase di Desa Bonebalantak, rumah ketua kelompok juga berfungsi sebagai rumah produksi bagi produk minuman herbal Sipa Mase Mase. Pelatihan dihadiri oleh ketua dan anggota dari ketiga kelompok mitra.
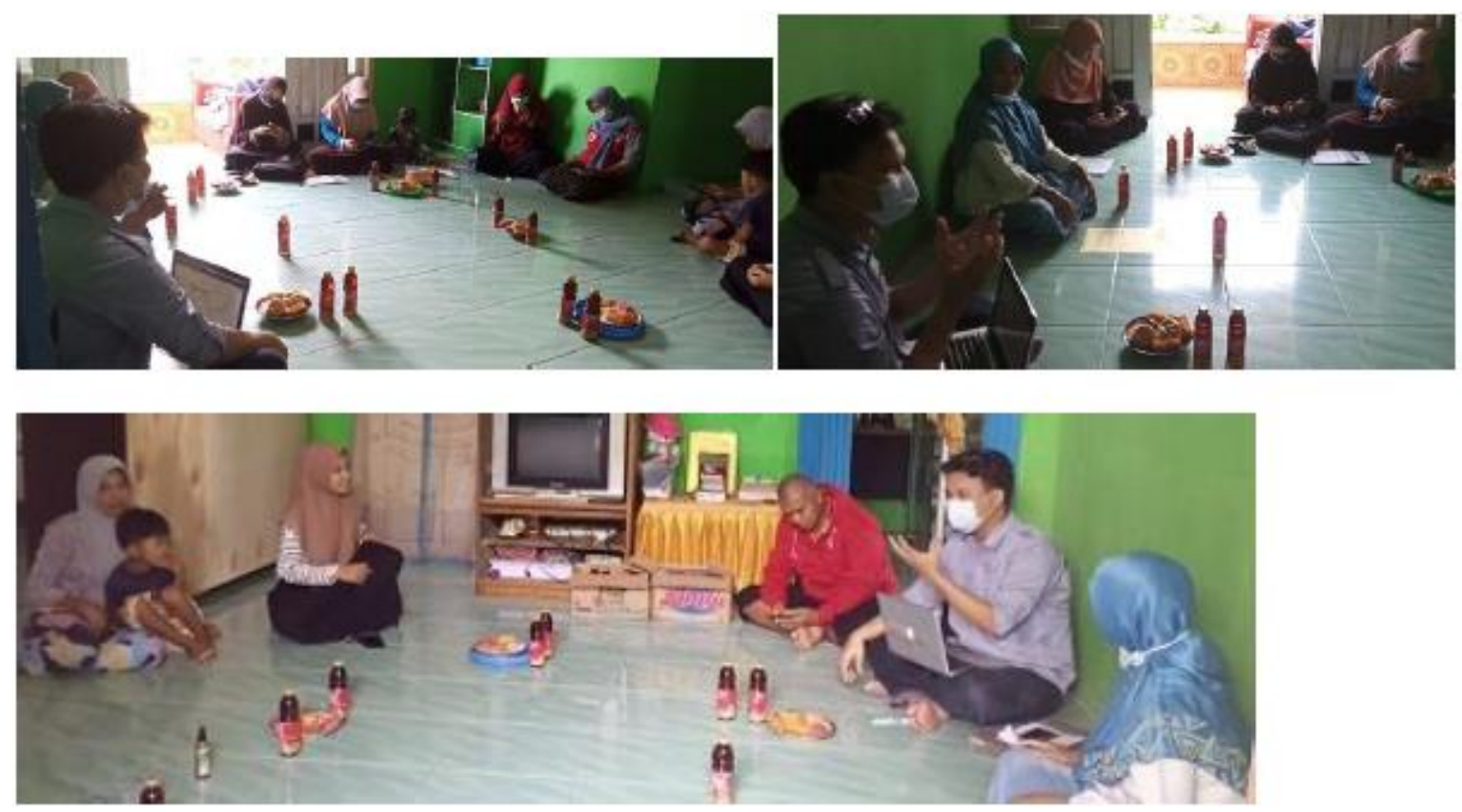

Gambar 3. Pelatihan Strategi Pemasaran

2. Pengenalan dan pelatihan pemasaran online melalui media sosial Instagram (IG), Facebook (FB) dan Whatsapp (WA)

Dari tahun ke tahun pengguna social media semakin bertambah. Hal ini membuat social media menjadi salah satu media pemasaran yang sangat efektif untuk memperkenalkan produk yang dimiliki usaha minuman herbal, melalui social media para pelaku usaha dilatih cara membuat akun social media, berupa Facebook, Instagram, Twitter, dan Whatsapp. Kemudian diisi dengan konten yang menarik dan konsisten memposting hal-hal menarik 
yang diselingi promosi produk. Misalnya, membuat postingan dengan foto produk semenarik mungkin dan menjelaskan mengenai produk tersebut dengan menambahkan caption menarik didalamnya. Untuk mendapatkan foto foto produk yang menarik, peserta dilatih terlebih dahulu cara mengambil gambar produk menggunakan handphone dengan latar belakang dan property menarik seperti gambar berikut :

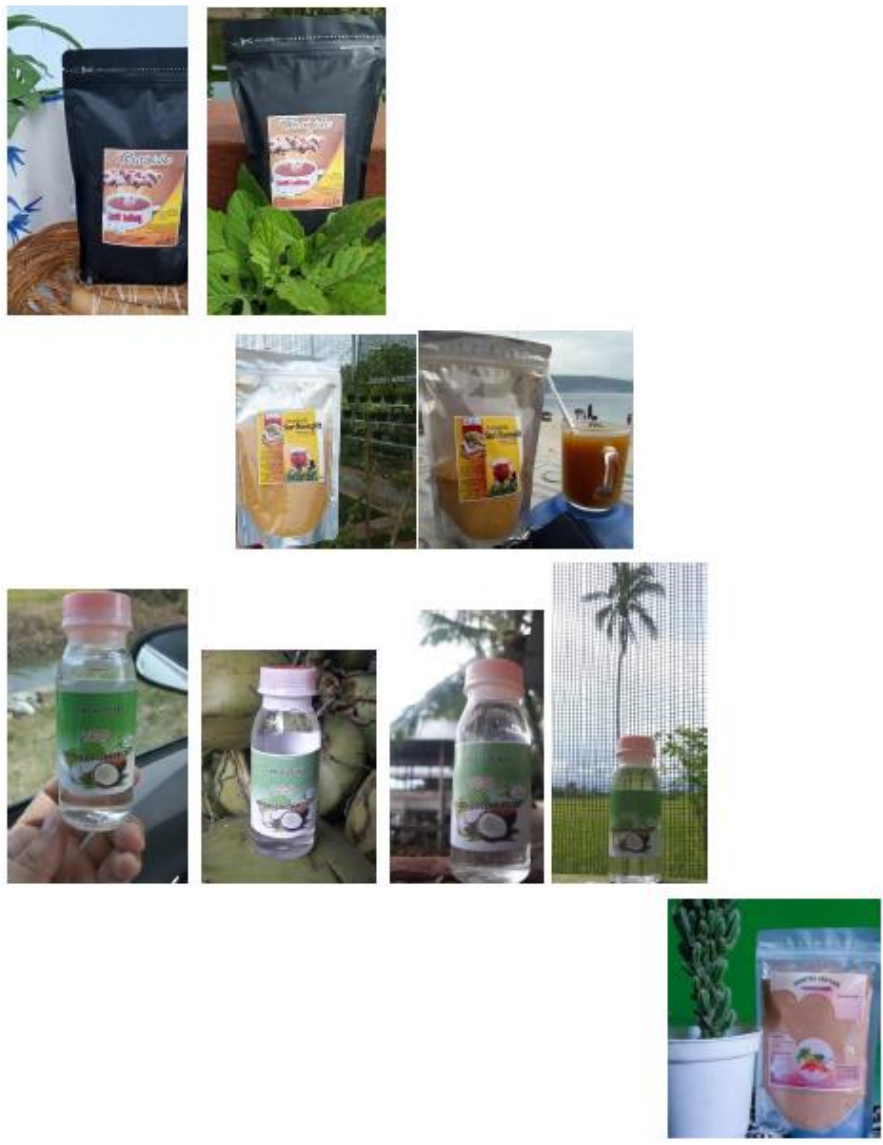

Gambar 4. Pengenalan dan pelatihan pemasaran online melalui media sosial Instagram (IG), Facebook (FB) dan Whatsapp (WA)

Kegiatan ini dilaksanakan dalam bentuk pengenalan dan pelatihan pemasaran online sebanyak satu kali, bertempat di rumah ketua kelompok Sipa Mase Mase di Desa Bonebalantak, Tempat ini dipilih karena terdapat fasilitas wifi untuk mendukung kegiatan pelatihan pemasaran online. Materi pelatihan dalam bentuk powerpoint dibagikan kepada masing-masing peserta. Saat kegiatan berlangsung, masing masing kelompok herbal didampingi untuk membuat akun media sosial Instagram (IG) dan Facebook (FB) kemudian menginput seluruh gambar atau foto-foto produk mereka ke marketplace Sophee. Kegiatan berlangsung secara interaktif dan peserta terlihat sangat antusias mengikuti, dan memang perlu pendampingan lebih lanjut, karena kegiatan pengabdian 
yang dilaksanakan oleh tim ini menghadapi keterbatasan waktu dan penganggaran. Berikut ditampilkan foto-foto suasana pelatihan dan pendampingan pemasaran online pada kelompok minuman herbal yang diikuti tiga kelompok yakni kelompok Cahaya Anugrah, Indo Lorong dan Sipa Mase Mase.
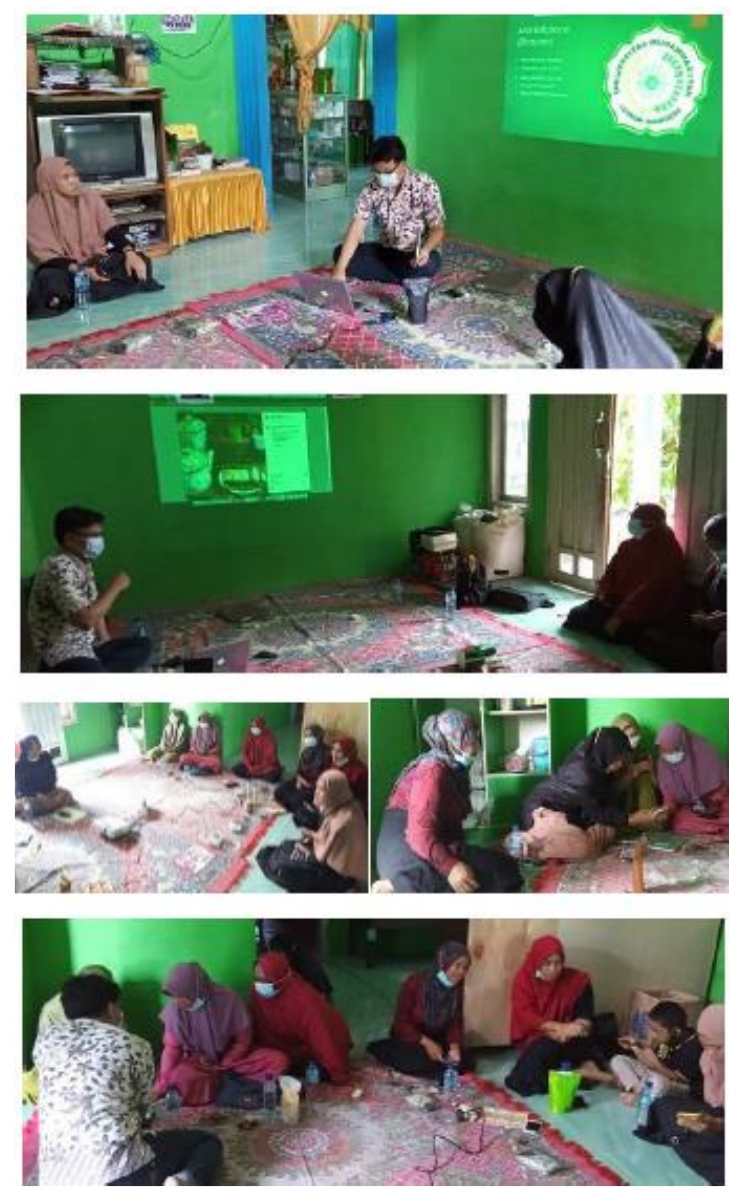

Gambar 5. Pelatihan dan pendampingan pemasaran online pada kelompok usaha herbal

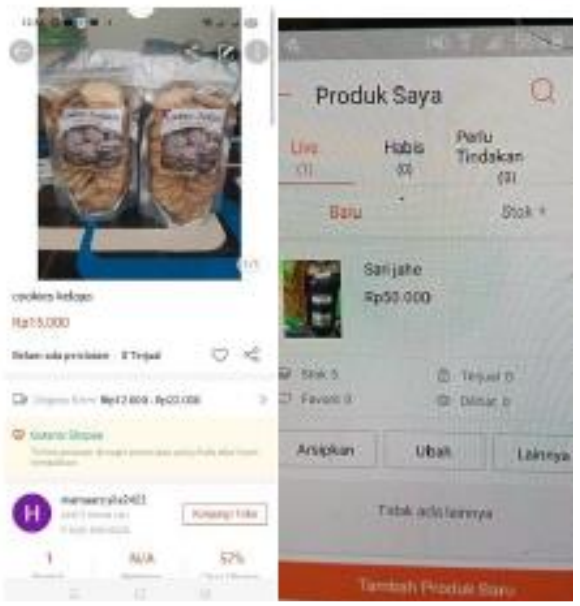

Gambar 6. Tampilan Produk Di Market Place Sophee 


\section{Diskusi}

\section{Meningkatkan pengetahuan dan keterampilan mitra tentang strategi pemasaran}

Strategi pemasaran meliputi strategi harga, promosi dan distribusi. Elemen-elemen dalam strategi pemasaran disebut juga marketing mix. Menurut hasil penelitian (Sari, 2017) bahwa UKM melaksanakan beberapa elemen bauran pemasaran, penyebab terbatasnya penggunaan elemen bauran pemasaran adalah karena hambatan yang dihadapi oleh galeristorey sebagai UKM. Strategi harga adalah upaya menetapkan harga yang tepat terhadap suatu produk herbal. Dalam kegiatan ini kelompok usaha herbal yang menjadi peserta pelatihan diberi pemahaman bahwa menetapkan harga jual produk harus mempertimbangkan beberapa hal, menurut (Layoo \& Botutihe, 2021) hal-hal tersebut yakni berapa harga yang bersedia dibayarkan oleh pelanggan, berapa harga yang ditetapkan pesaing, berapa total biaya yang dikeluarkan per unit produk, serta bagaimana cara membuat harga agar menarik pelanggan yang biasa dikenal dengan penetapan harga psikologis.

Demikian pula promosi yang lebih ditekankan pada promosi melalui media sosial instagram, facebook dan Whatsapp terutama ketika masa pandemi covid dimana pelanggan membatasi mobilitasnya di luar rumah, dan penggunaan media sosial di kalangan masyarakat yang semakin hari kian tinggi. Pembelajaran strategi promosi yang diberikan adalah tentang pentingnya merek produk herbal yang berkonotasi positif, uraian komposisi dan manfaat produk herbal, tampilan produk dan tagline yang menarik. Selama ini pelaku usaha minuman herbal tidak melakukan aktivitas promosi yang berarti sehingga dalam pelatihan ini ditekankan perlunya sikap proaktif dalam mengenalkan produk yang dihasilkan. Menurut hasil penelitian (Layoo \& Rahman, 2019) bahwa untuk meningkatkan kinerja perusahaan, pelaku UMK di Kabupaten Banggai harus mampu memelihara dan meningkatkan orientasi kewirausahaan yang meliputi sikap inovaif, proaktif, keberanian menanggung risiko, otonomi dan keagresifan bersaing. Setelah kegiatan ini anggota kelompok menjadi paham akan pentingnya promosi melalui platform digital.

Sedangkan distribusi produk herbal dimasa pandemi yang lebih mengandalkan distribusi langsung dari kelompok usaha herbal ke pelanggan menggunakan jasa pengiriman barang untuk menjangkau pelanggan yang tersebar melintasi batas-batas geografis. Moda transportasi yang paling banyak digunakan adalah mobil angkutan umum, kemudian kapal laut dan pesawat udara. Pembelajaran strategi distribusi yang menjadi perhatian kelompok usaha herbal terkait keamanan produk yang harus terjamin hingga produk diterima pelanggan, biaya pengiriman yang terjangkau, serta jasa pengiriman yang terpercaya.

\section{Meningkatkan keterampilan menggunakan media sosial IG, FB dan WA untuk pemasaran online}

Dampak pandemi Covid 19 membuat pertumbuhan sektor industri pengolahan terkontraksi cukup dalam. Kebijakan pembatasan pada semua aktivitas masyarakat yang bertujuan mengurangi 
penyebaran pandemi membuat usaha industri mikro kecil (IMK) yang tidak dapat beroperasi secara normal. Hanya sebagian kecil saja dari kelompok kegiatan usaha IMK yang justru mampu menangkap peluang di masa pandemi ini. Kelompok usaha industri ini adalah industri yang berperan dalam penanganan pandemi COVID-19, seperti industri farmasi, dan obat tradisional (BPS, 2020)

Oleh karena itu untuk meningkatkan kapasitas kelompok usaha obat tradisional atau herbal pada masa pandemi diperlukan keterampilan pemasaran secara online, dan upaya ini disambut antusias oleh kelompok mitra, apalagi sebelumnya mereka belum memiliki pengetahuan dan keterampilan terkait pemasaran melalui media sosial instagram, facebook dan whatsapp. Menurut Indonesian digital report (Layoo \& Botutihe, 2021), pada tahun 2020 persentase pengguna internet setiap platform di Indonesia adalah whatsapp 84\%, Facebook 82\%, dan instagram $79 \%$.

Pasca dilakukan kegiatan ini kelompok usaha herbal yang menjadi mitra telah memiliki pengetahuan pemasaran melalui marketplace sophee, memiliki akun instagram dan facebook, mampu membuat dan mengupload foto-foto produk yang lebih menarik dan instagramable. akun media sosial tersebut dan memanfaatkannya untuk memasarkan produk-produk yang dihasilkan.

Meskipun demikian kelompok usaha herbal di Batui Selatan masih perlu pendampingan lebih lanjut terkait pemasaran secara online, dan hal ini dapat dilakukan bersama sama instansi pemerintah terkait seperti Dinas Koperasi dan UMKM, Dinas Pemberdayaan Perempuan, dan Dinas Perindustrian dan Perdagangan

\section{Kesimpulan}

Setelah melaksanakan kegiatan pengabdian ini, maka disimpulkan bahwa Pelatihan strategi pemasaran mampu meningkatkan pengetahuan dan keterampilan mitra tentang strategi harga, promosi dan distribusi. Pengenalan dan pelatihan pemasaran melalui media sosial Instagram, Facebook dan Whatsapp mampu meningkatkan keterampilan menggunakan media sosial IG, FB dan WA untuk pemasaran online produk-produk herbal.

Ucapan Terimakasih

Penulis mengucapkan terimakasih dan penghargaan setinggi tingginya kepada Rektor Universitas Muhammadiyah Luwuk dan ketua LP3M Universitas Muhammadiyah Luwuk atas support pembiayaan kegiatan ini, kepada kelompok usaha herbal yang menjadi mitra atas atensi dan kerjasamanya. 


\section{Daftar Referensi}

BPS. (2020). Industri Mikro dan Kecil di Masa Pandemi COVID-19. https://www.bps.go.id/publication/download.html?nrbvfeve=ZDJmZjk3Y2MzNjV1OThlZWR kNGZhZDdm\&xzmn=aHR0cHM6Ly93d3cuYnBzLmdvLmlkL3B1YmxpY2F0aW9uLzIwMj EvMDgvMjUvZDJmZjk3Y2MzNjV1OThlZWRkNGZhZDdmL2luZHVzdHJpLW1pa3JvLW Rhbi1rZWNpbC1kaS1tYXNhLXBhbmRlbWktY292aWQtMTktLTIwMjAuaHRtbA\%3D\%3 D\&twoadfnoarfeauf=MjAyMS0wOS0yNiAxNjo1OTo1OA\%3D\%3D

Diko, M. D. R., Ladjin, N., Haluti, F., Layoo, N., Tasruddin, Wuniarto, E., \& Samaduri, L. (2020). Monitoring dan Evaluasi Program Pemberdayaan Kelompok Nelayan dan Kampung Herbal. (Tidak dipublikasikan)

Layoo, N., \& Botutihe, N. (2021). Perencanaan Bisnis untuk Mahasiswa dan Umum. Widina Bhakti Persada Bandung.

Layoo, N., Haluti, F., Diko, M. J., Ladjin, N., Tasruddin, Wuniarto, E., \& Samaduri, L. (2020). Indeks Kepuasan Masyarakat Program Pemberdayaan Kelompok Nelayan dan Kampung Herbal. (Tidak dipublikasikan)

Layoo, N., \& Rahman, W. (2019). Pengaruh Orientasi Kewirausahaan Dengan Kinerja Usaha Mikro Kecil Di Kabupaten Banggai. Jurnal Ekonomi Pendidikan Dan Kewirausahaan, 7(1), 29-44. https://doi.org/10.26740/jepk.v7n1.p29-44

Sari, R. (2017). Marketing Mix Implementation in Small Medium Enterprises: A Study of Galeristorey Online Business. Etikonomi, 16(April), 115-125. https://doi.org/10.15408/etk.v16i1.3950 